\title{
Destination image, image at destination. Methodological aspects
}

\author{
Pablo Díaz-Rodríguez \\ Agustín Santana-Talavera* \\ Alberto Jonay Rodríguez-Darias
}

Instituto Universitario de Ciencias Políticas y Sociales. Univ. La Laguna

\begin{abstract}
Today, the part played by the image in the development of tourism, and, specially, as a differentiation element of a destination area is widely acknowledged. This is reflected to a great extent in the literature that focuses its interest on identifying the variables that motivate the purchase or stimulate the decision process. However, the reference to feedback processes or image control mechanisms as well as their creation, is surprising. An approach model to these processes will be exposed in this article.
\end{abstract}

Key words: Image destination; cultural hybridization; motivation; decision processe.

\section{Introduction}

Competitiveness, dynamism, innovation, and entrepreneurship are relevant components of the tourist system, and references to them are found in almost any academic article, institutional declaration, implementation project or request for benefits that the tourist activity implies. The tourist system is the pure reflection of the binomial enterprise-consumption and its associated lifestyles imported from the western economies. The 'paper napkin's' consumption-culture, the hailing of the ephemeral usage of goods is reflected in tourism in the demand of a constant renovation, of shape or content, in the products and destinations. Some of these renewed elements are obvious, and their consumer is a participant of the service, the activities or the complements to leisure time that trends may lead. However, others are not so evident, and behind the aesthetic conditioning, there's the offer of opportunities, recently created traditions and reinterpretations of the nature and culture of which the client is a willing accomplice. Both are the contexts of the 'destination image' and of the 'image at the destination' that, stale or influenced by virtual qualities and technologies, are created, consumed and reproduce markets and consumers in a paradoxical game of continuity and renovation, of familiarity and contrast, of tradition (reference to the past rebuilt to taste) and modernity. All of it displayed without cracks, as a whole only dividable if the customer so wishes or can do it on his/her own.

A limitation that occasionally goes unnoticed is that the imaginaries and their referents must be chosen, combined and differentiated to a more or less defined market-clientele (codes and socio-cultural groups, economic and educational level, age range, demands...). Furthermore, at the same time, image is constrained by a series of available physical elements (attributes that want to be resources that want to be products) and a business and hardworking population that must also adapt or show itself flexible enough to seasonality, changes of consumers groups, the work circumstances, etc., and also a resident population that must adjust itself to the

* E-mail: asantana@ull.es 
changes that happen around it. A multivariate and multi-causal process in a constant situation of change that from a cyclic perspective (TALC de R. Butler, 1980; Baum, 1998 and Agarwal, 2006), of networks (Pavlovich, 2003) or evolutional (Breakey, 2005; Awang et al. 2009; Ma\& Hassink, 2013), has been described and is still under discussion and advancement.

Currently there is a wide interdisciplinary consensus on the importance that the image has as the system's core and motor while promoting the motivation, the purchase and the consumption in the destination. A good example of this is that only the studies on the impacts of tourism draw the same level of attention in the developed researches. Such relevance can be seen in works such as the ones by Gallarza, Gil Saura and Calderón García (2002), and Frías, Rodríguez and Castañeda (2007), who have made a comprehensive and thoughtful review of the bibliography about the image, or Baloglu and McCleary (1999), who, in a text that has marked several later researches, review the main works that have been developed about items such as the impact of the visit, the image's familiarity, the relation between the tourist's geographical location and the image, measure of the destination image, its components and influential factors; the difference between the tourist's image (demand) and the image displayed by the destination, the variations in the image according to the trip's purpose, or the relation between socio-demographical variables and the destination image.

As a whole, it is possible to distinguish three approaches among the different types of studies on the image: those of static structure, that examine the relation between the image and the tourist's behaviour; those of dynamic structure, that focus their interest on the conformation and production of the tourist destination image; and those of consequential structure, focused on the image's effect on the system's set of actors. Nonetheless, given the dynamic conception of tourism as an open system, the study of the relation between the different approaches seems indispensable. In this sense, none of the multiple elements and complex processes that constitute the tourist system is separated from the rest, nor detached from the outside world, as the system itself is intrinsically and mutually related to other systems. It is precisely this characteristic of constant interdependence that gives the tourist system a high degree of openness, flexibility and dynamism, and, with that, it constitutes itself as re-adaptable to the different conditions of the surroundings (physical, sociocultural and economical), giving space to new problems. This text presents itself as a reflection tool on the phenomena and processes related to the tourist images, from the development of the analysis model followed by this research team, based on that systemic conception of tourism.

\section{The image's conceptual construction}

Since the nineties (Um and Crompton, 1990; Chon, 1991; Gartner, 1993; Gallarza et al., 2002) one is prone to consider the image as a complex and subjective conceptual construct (Bigné, Sánchez, and Sánchez, 2001) in which emotions and reasoning of the consumer are melted with assessments that compare the experience and the knowledge about the destination. Bibliography stresses how this gets a leading role, being understood as a global, holistic sensation, from the set of impressions that a visitor of a place has. (Echtner and Ritchie, 1991; Gartner, 1993; Coshall, 2000; Gallarza, Gil and Calderón, 2002). In the same way, the perception is converted into a concept linked to the image, being this one constituted by the 'mental representation' or 'global perception' of the multiple components of the tourist destination on the part of the consumer tourist (cognitive component; Hunt, 1975; Assael, 1984; Gartner, 1986; Calantone et al. 1989; Echtner and Ritchie, 1991; Coshall, 2000; Murphy, Pritchard and Smith, 2000; Bigné and Sánchez, 2001) and the valuations and feelings that are awaken (affective component) (González Bernáldez, 1981, 1985; Baloglu, S. and Brinberg, D., 1997). This way, one understands that the image is constituted as a subjective concept, i. e., as "the interiorisation of the perceptions" of the tourist. (Gallarza, Gil and Calderón, 2002). This type of conception is integrated in a changing notion of the image, focused both in the physical attributes of the destination's area, and the perception on the part of the consumer-tourist, who is the one that finally shapes, out of all of it, a unique photogram charged with sensibilities, emotions and evaluations, both cognitive and affective. (San Martín Gutiérrez,Rodríguez del Bosque Rodríguez and Vázquez Casilles, 2006). Thus, image becomes individualized (since the definition brought in by Hunt, 1975), and, furthermore, marked by the role of activity-passivity played by every tourist during his/her trip (Mercille, 2005), circumscribed to consumption and associated marketing.

It is understood that this perspective of the image's analysis would set aside other actors and dynamics implicated in the process of design, formation and transmission that will strike the 
imaginary of destination and at the destination. I. e., on one hand, the profile that the implicated groups at the origin (locals and residents, institutions and politicians, business men and investors, operators and retailers) display of their area (territory, history, beliefs, language, activities, products, etc.) in the construction of the destination's identity, which will identify it as such (uniqueness) or by subjective comparison with others. And, on the other hand, the different cultural variations that will be offered in the tourist contact and, in their case, taken in as valid cultural modifications. In this sense, it is understood that the image in the system is, practically, the item that sets the destination and largely determines the satisfaction and the tourist recollection, mainly by comparison, in the experience of being a tourist of a destination. But, yet, the socio-cultural effects on local populations of images foreign to themselves, or prepared for their better understanding and consumption by the others, are felt in the medium term, changing patterns and behavioural traits, values and relations, reconstructing the local identities (Franklin and Crang, 2001). The tourism system thus plays an important role as a signifying and resignifying agent of the territory and landscape (its aesthetical version). Thus, the genesis of an important part of the tourist destinations depends more on the images that are displayed, than on the real characteristics of the space to visit, creating a reinvented landscape, both for investors and for tourists (Valcuende del Río, 2012).

With the benefits of hindsight, it seems necessary to look at the image in a global manner, which implies to clearly differentiate between the process of conception, design and of putting in usage the materials that shape the displayed image (campaigns in areas of demand and destination, actions to foster the coincidence between the exhibited and the available, improvements in the profiles presented for each consumer typology...) and the perception and intake processes ('creation' and individual comparison). It's about opening the schemes and models of research to a twofold track of feedback and interconnected processes that methodologically allow a step-bystep study with valid indicators in each one of them. Thus, one contemplates a set of seven subprocesses of the global image, interconnected but operationally dividable, both in their analysis and in their implementation (Table 1).

It is usually supposed that the attributes on which a destination image rests are partly physical (a surrounding, infrastructures, climate) and partly tangible (culture, kindness, familiarity, well-doing, identity, service promises or activity, creation of experiences compromises and living of emotions). It is in this context of new quests that the resident populations, formerly passive actors, become consubstantial part of the image constructed for the motivation at the consumers' source, and that the 'self-image' (the one that the residents perceive of themselves and of the area in which they live) becomes important.

Whilst the 'self-image's study is seldom incorporated in the tourist analysis, that did not happen to its attitudes towards tourism (Getz, 1994; Ryan and Montgomery, 1994; Lindberg and Johnson, 1997; Lawson, Williams, Young and Cossens, 1998; Smith and Krannich, 1998), given the importance granted to the way they possibly affect the perceived image. The incorporation of the self-image can bring truthfulness to the campaigns, identifying attributes and avoiding unnecessary performances, but also establishing limits (spatial, qualitative or temporal) (Kolozovsky, 1986) to development or to tourist exploitation of the areas. It is understood that the self-image may not be unique, inasmuch that it will depend on the different socio-cultural groups that will adjust the local population of the area and the levels of integration of the foreign population with those groups and between them. But whereas that it is influenced by the images offered to tourism, in the long term, it may get simplified to a great extent. In an ideal situation, a major part of the self-image may be reflected at least in the image made for sale, and, finally, in the sold image, but this seldom occurs. The ideal representations that each one - each group may have of itself and its territory (more productive than aesthetic) are hardly fitted by the demand for the mythical place, paradise in its multiple and changing versions, that may coexist in the tourist generating countries. For this reason, it's not odd to find constructed and advertised images about virtual resources, fleeting or too adorned, and neither is the inclusion as atrezzo of such variable elements as the climate or social events, which make invisible the rest of real aspects that aren't consistent with the imaginary intended to be constructed.

As previous backdrop, the self-image, the daily life (through the economic and organizational efficiency to the resident population and the demands of the market logic), is conceived in a copy, whose quality is measured in terms of its adaptation to consumption. It is converted in an argument for its sale as a constructed image, showing the ease of access, innocuousness and exoticism, in the classical model, or danger, risk, distress and adventure, in the most refined forms of design of the new tourist experiences, more or less charged with sensationalism, whether we move from 'authenticity' to 'reality' marketed by tourism. Motivations, expectations, 
Table 1. Deconstruction of the implied processes in the tourist image.

\begin{tabular}{|c|c|c|c|c|c|}
\hline & $\begin{array}{c}\text { TYPE } \\
\text { OF IMAGE }\end{array}$ & DESCRIPTION & MEDIA & $\begin{array}{c}\text { TYPE OF } \\
\text { INFORMATION }\end{array}$ \\
\hline \multirow{4}{*}{ 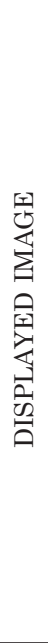 } & \multirow{4}{*}{ 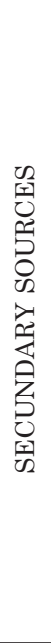 } & $\begin{array}{l}\text { Constructed } \\
\text { Image }\end{array}$ & $\begin{array}{l}\text { General image created at the } \\
\text { destination to attract specific con- } \\
\text { sumers according to the different } \\
\text { interests. }\end{array}$ & $\begin{array}{l}\text { Cinema, literature, } \\
\text { documentaries, guides, } \\
\text { etc. }\end{array}$ & - Autonomous \\
\hline & & $\begin{array}{l}\text { Promoted } \\
\text { Image }\end{array}$ & $\begin{array}{l}\text { Adequacy on the part of institu- } \\
\text { tions and enterprises oriented to } \\
\text { the marketing according to the } \\
\text { concrete demand for the products } \\
\text { or attract consumers according } \\
\text { different interests. }\end{array}$ & $\begin{array}{l}\text { Leaflets, web pages, } \\
\text { adverts, virtual social } \\
\text { networks, etc. }\end{array}$ & \multirow{2}{*}{$\begin{array}{l}\text { - Obvious } \\
\text { (conventional } \\
\text { advertising of local } \\
\text { institutions and who- } \\
\text { lesale enterprises) } \\
\text { - Covert } \\
\text { (Non evident } \\
\text { promotion using } \\
\text { famous people, news } \\
\text { coverage or non } \\
\text { advertising articles) }\end{array}$} \\
\hline & & $\begin{array}{l}\text { Re-created } \\
\text { Image }\end{array}$ & $\begin{array}{l}\text { Tour-operators' selection and } \\
\text { combination of products and } \\
\text { destinations suiting the demand. }\end{array}$ & $\begin{array}{l}\text { Catalogues, leaflets, } \\
\text { posters, adverts, etc. }\end{array}$ & \\
\hline & & $\begin{array}{l}\text { Sold } \\
\text { Image }\end{array}$ & $\begin{array}{l}\text { Individual modification in the sale } \\
\text { process by the retailers (tourist } \\
\text { enterprises, travel agencies...). }\end{array}$ & $\begin{array}{l}\text { Individualized commu- } \\
\text { nication }\end{array}$ & - Direct \\
\hline \multirow{3}{*}{ 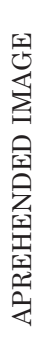 } & \multirow{3}{*}{ 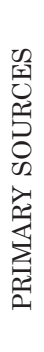 } & $\begin{array}{l}\text { Self- } \\
\text { Image }\end{array}$ & $\begin{array}{l}\text { Local way of conceiving themsel- } \\
\text { ves and their surroundings. }\end{array}$ & \multicolumn{2}{|c|}{ Daily life and displayed images. } \\
\hline & & $\begin{array}{l}\text { Perceived } \\
\text { Image }\end{array}$ & $\begin{array}{l}\text { Interpretation and valuation of } \\
\text { the visit. }\end{array}$ & $\begin{array}{l}\text { Experience of the visi- } \\
\text { ted place, stereotypes } \\
\text { and expectations } \\
\text { previous to the visit. }\end{array}$ & \multirow{2}{*}{$\begin{array}{l}\text { - Organic (infor- } \\
\text { mation transmitted } \\
\text { by relatives and } \\
\text { friends ) } \\
\text { - By the visit's } \\
\text { experience }\end{array}$} \\
\hline & & $\begin{array}{l}\text { Shared } \\
\text { Image }\end{array}$ & $\begin{array}{l}\text { Setting of the recollection and } \\
\text { transmission upon arrival at the } \\
\text { point of origin. }\end{array}$ & $\begin{array}{l}\text { Photos, souvenirs, } \\
\text { individualized com- } \\
\text { munication, virtual } \\
\text { social networks, etc. }\end{array}$ & \\
\hline
\end{tabular}

Source: own elaboration based on Santana (2009) and Beerli and Martín (2004).

and multidimensional activities (Villa, 2001), that are reflected in the image's complexity and intangibility.

Image is often drawn according to the interest of diverse stakeholders. It is usually found with three, more or less limited, strategies: (i) a joint participative (collaborative) policy of all the involved in the design of such an image (direct actors in the destination), in the selection of the attributes, conjunction of products and their physical and emotional reference points for the destination's identity. (ii) A more or less interested selection done around the products and activities available in the area, grouped by theme blocks or sub-territorial areas, and (iii) a conglomerate of initiatives, more or less compatible and generally exogenous, that tend to overrate the destination's attributes, such as resources, supposing their demand (common, yet nonexclusive, in forms of image that intend to stimulate cultural tourism, ethno tourism, etc.).

Whatever the case may be, the ideas that compose such designs have to be materialized in several advertising campaigns, thus forming what has been denominated advertised image. A design marked for merchandising, to a great extent oriented by the demand and the campaign's creatives, about some attributes more or less present in the area, and by the constructed image. Regional and local institutions, and, to a lesser extent, businessmen will contribute to its configuration. Through the analysis of recent promotional campaigns it's observable how the 'creator leader' (person or group) of the tourist organizations-institutions prints his/her brand seeking to consolidate (often by legislative periods): destination projects that express a certain level of quality (conditioned by the destination's competence and identity); honesty (no cheating the client); preparation (professionalism in the offered services and products); and response capacity to the values and wishes of a group or segment of the targeted market segment (tendency for tourism à-la-carte). Attaining goals (number, frequency and type of tourists) and organization maturity (persistency) will determine to great extent the project's strength, and, within the limi- 
tations and uncertainties of the tourist system, their real durability (successful time in the market).

Although drastic changes seldom occur, the passage of the constructed image to the perceived one compels to small adjustments in order to adapt to the needs of merchandising facing concrete market segments (potential tourists), the variations in the demand and the competence of other destinations. This form taken by the image is both enormously flexible (allowing certain alterations by changing products or enhancing new resources) and definer of the destination facing the consumer (who imitates the previous characteristic). The advertised image, with an important physical component, tangible, that is reflected on pamphlets, leaflets, stickers, posters and other forms of advertising material, is the one that can be found with other props in the tourist holidays. These are addressed, mainly, to tour operators and retailers or travel agents, although in some occasions it is possible that big campaigns are made to reach the greater audience.

The general importance of this component of the global image is rooted in its position as a conscious and unconscious motivator that encourages the individual to join the tourist current, through symbolic stimuli that evoke certain states of mind (relaxation, adventure, discovery, entertainment, etc.). In a more concrete scope, its objective is to contribute to consolidate the purchase decision on a destination and a determined type of tourism. At this point, the advertised image can be assigned both the role of generator an strengthener of stereotypes about the destination (of group character) (Echtner y Ritchie, 1991; Gallarza et al., 2002) and of expectation's promoter (of individual character) (Litvin and MacLaurin, 2001; Litvin and Ng Sok Ling, 2001) about the area, the advertised products and the emotions caused by their consumption. Nonetheless, it must be understood that the image of the tourist destinations is incremental, i. e., not directly replaceable from one promotional campaign to the other. Thus, areas with a negative or degraded image will have to commit much more effort, resources and time (Fakeye and Crompton, 1992) than others with a strong positive image, to be included in the pool of eligible destinations in the processes of decisions making (Frías et al., 2007). However, determining the elective destination is also conditioned by other factors, fundamentally economic costs, discounts and payment possibilities or debt), temporal (seasonality, coincidence with non-labour or school periods) and incidental (presence of underage or elderly people, weather, safety, time of travel, etc.).

Although destination areas increasingly promote themselves (proposing themselves as eligible), they are not often charged of their products sales' processes (like reservation centrals). The market is monopolized by some multinational group operators (Wholesale agents) (up to $55 \%$ of the holidays booked in the United Kingdom in 2001, according to Parra López, Melchior Navarro and Ramos Domínguez, 2003). Adapting to the demand, generating it, and a better business composition (Martin de la Rosa, 2003), tour operators may combine both products of a same destination, and products of differentiated areas, and including several destinations with all their products. They can even create totally new products (mainly services) that will be inserted in determined destinations. Thus, one can recognise a re-created image, which can be nonhomogenously launched into the market by the different operators, parallel to the advertised image that will be injected by the institutions, organizations and, seldom, enterprises (Andreu, Bigné and Cooper, refer to the sent image that, in the proposed conceptual scheme, we have methodologically subdivided in advertised and re-created image).

In this process, the tour operator brings the trip closer to the consumer, making his/her adaptation and purchase of a specific product (set of goods and services) possible. This gets to the client through the travel agencies (retail agents) that may substantially modify, positively or negatively, the images and impressions that he/she may have created about the destination so far. The travel agent doesn't usually know firsthand neither the destination, nor the products, nor the advertised (an even less the one made for sale) with which he/she ultimately interprets and offers the possible consumer destination-product(s). This is done based on the material supplied by the tour operator (recreated image) and the salesperson's experienceskill itself. In practice, the information provided by the travel agents again introduces some variations, not unimportant ones, in the image, shaping the sold image. Both images, re-created and sold (corresponding to the distribution channels as active subjects) are those that consolidate concrete expectations about the potential client-tourist who acquires the temporally limited enjoyment of products made up of goods, services, activities, territory, climate, landscape, culture, etc. Or, which is the same, he/she pays for temporal and agreed on appropriation of the destination and the repeatable experiences in it.

The displayed images (advertised, re-created and sold) are defined from a series of variables or codes (adapted from Ronai, 1976). These are:

(1) The psychological code: from which one searches for figures or representations that evoke emotions or revive experiences. 
(2) The aesthetical code: the set of colours, distance, texture, etc., that presents the surroundings as anthropic or physical work of art.

(3) The unconscious code: attributing the wanted destination adjectives that may orient the receiver on the form of a subliminal message.

(4) The mythical code: reference to the irrational, the fantasy, the lost paradise, with certain characteristics of its people, but always emphasizing, and according to the receiver, its archaic character, or its progress.

(5) The strategic code: highlights the privileged position, based on the values that are meant to stand out.

(6) The geographical/human code: epic exposure of physical characteristics, such as geomorphology, climate, etc., giving a special importance to contrasts. The inhabitants of the area are treated the same way, and so are the traits that one wants of it.

(7) The infrastructural code: the communication with the destination, but emphasizing the vectors pertaining the commodity for the holiday and/or the trip, highlighting the possibility of evasion, or, if appropriate, the environmental ideologies.

These can operatively be simplified and broken into four categories of elements: (i) functional (mobility, infrastructures, possibilities of relation or activity); (ii) picturesque and grandiose (peculiar scenes with artistic qualities, monumentality and landscape architecture); (iii) emotional (evocation of feelings); and (iv) unique (tangible or intangible attributes exclusive to an area and only of it).

Equally important, the layout of the destination-spectacle, where everything that happens can be constructed and regulated as an attractive, concludes with its presentation to the consumer population with style uniformity, vocabulary and thematic diversity (according to the groups of target consumers) and standard representative icons. Depending on the products and specific tourist activities (reality tourism, voluntourism and similar forms are set aside), a fundamentally aesthetic valuation of the area happens, hiding possible contradictions, both between the space and the rest of the hosting society, and between the social groups that compose it, offering an apparent harmony.

\section{Individuality and recollection in the tou- rist image}

The subject of the glance, the tourist-actor apprehends the image as a part of his/her daily processes and as an object of the culture that he/she visits (normally hidden behind the veil of the tourist activity) in an exercise of codification, interpretation and comparative valuation from their way of life and culture of origin, mediated by the tourist system. The spatiality and temporality of daily life are limited in the destination, if not suspended beforehand, reinforcing the immanent (essential) character of the one created for enjoyment. This is the place in which the image is completed. Therefore, the perceived image is shown as a total set (Assael, 1984) of beliefs, ideas, and impressions of the visited place (Crompton, 1979), overlapping the stereotypes and expectations accumulated before the visit.

In this sense, the individual image as a mental representation goes through a large process of formation that can begin even before the potential client has the motivation to travel. This can happen indirectly, inasmuch as the individuals have access to global information that is being themed according to personal interests, as well as group, social, political, environmental ones among others, which results in the emergence of specific states of opinion and knowledge. A preset of simplified images and stereotypes (the 'organic image' proposed by Gunn, 1972; developed by Fakeye and Crompton, 1991) according to socio-demographic characteristics (sex, age, education and socio-economic level, mainly). Surely this type of indirect information is usually vague and inaccurate, but it predisposes individuals to the reception of more elaborate speeches in a tourist fashion (induced image, according to the same authors, or projected image, according to the previous conceptualization) and, consequently, to a greater probability of occurrence of motivations (Castaño, Crego and Moreno, 2006) and selection of a concrete type of destination.

Baloglu and McCleary (1999) clarify that the image duration rests on the direct or indirect knowledge of the actual attributes of a place about which emotions are generated, differentiating between stimulus factors (information sources according to quantity, type, previous experience and distribution) and personal factors (psychological - values, motivations and personality - and social - socio-demographic characteristics). In the empirical application of this model, Beerly and Martín (2004) develop 
a categorization of the stimulus factors, distinguishing between secondary sources (basically perceived information before the visit, distinguishing between organic, induced and autonomous) and primary sources (formed during the visit in question). They also determine the important influence of the first (mainly of the sources of induced information - distribution channels - and autonomous - travel guides - ) as determining factors of the destination's choice and of the global perceived image.

Although the tourist's individual characteristics will, to a greater or lesser extent, condition the apprehension of the destination image and its evaluation, the stereotypes that nowadays are disseminated by the mass media (Bardón Fernandez, 1991) distort it and try to force the individual to adapt his/her own observation/participation to the image that turns out to be the most convenient to the tourist business (more profitable and less costly). And something similar, but with more lasting consequences, happens to the destination populations. All seems to indicate that the experience as a tourist and the clients' socio-cultural original provenance, not their nationality directly (Beerly and Martin, 2004), will influence both the cognitive and affective aspects of the perceived image. Both aspects base their relevance in the capacity and knowledge of the comparison of images, attributes, services and experiences of the destination, with the ones lived before during their travels or daily life, and also with the pre-trip expectations. In this sense, the impressions and emotions are always subjective (and hardly quantifiable) and, although related, they are found separated from the tourist destination's tangible elements. Attributions that are appraisingly confronted are almost specifically done on these elements, highlighting not only the indicated similarity or difference, but also tending to generalization by analogy.

Previous studies (Cruz Modino, 2004; Pinto da Silva Santos, 2010; Rodriguez et al., 2010; Rodriguez Darias, 2011) show that, although the tourist in the destination is continuously in an exercise of contrast (including with the most familiar), any unexpected or anomalous element will be included in the affective balance and positively or negatively evaluated. Facing the similarity of aspects, qualities or relations with a previously experienced situation, the individual will develop emotions and forms of behaviour as if he/she were responding to that initial situation, affecting the perceived image at the present moment. Being based on impressions, this process is one of the reasons for which the destination's perceived image may move away (Gartner, 1993) from what the resident population and the destination's permanent agents may consider, let it be carefully said, an objective or real image.

The confrontation, on the tourist's part, of the perceived image (manifestation of the encounter; Santana Talavera, 2003) with the game of nonpredictive expectations and stereotypes taken from the organic and displayed images, results in a evaluative judgment (cognitive affective) of his/her experience. That is what is known in tourism as 'satisfaction' (Westbrook, 1987; Echtner and Ritchie, 1991; Bigne et al., 2001). Being the profit maximization the final objective of tourism - to deny it is part of utopia - , the main concern of the destinations is to get a high level of satisfaction of their clientele, and, if possible, to retain both these tourists and their relatives. But, as it has been pointed out, many factors may distort the perceived image (Teye, Sönmez and Sirakaia, 2002) and with it, affect the levels of satisfaction (understood in a continuous bipolar gradation of no satisfaction-satisfaction) and dissatisfaction (equally of no dissatisfactionsatisfaction) (Westbrook, 1987). Through this, it is necessary to determine, not only such levels in a global way, but also to break them down at least into the same variables and factors used for the image's analysis and the creation of expectations, expressing them in gradient mode.

The tourist's experience is to be understood this way, as a set of life experiences that begins in the conscious motivations (Table 2), developing in the trip, the stay at the destination and return to their normality, concluding with setting of the recollection, its communication and the self-comparison with his/her peers (Shared image).

\section{Operationalization of the proposed model}

The analysis of formulated general image model poses the important difficulty of its multidimensional nature of spaces and actors, insofar as it not only implies the destination in itself, but also has to contemplate the cultures and implied cultural variations and processes of change (diachronic perspective). The complexity is evident when reviewing the different research designs that have been used, in which only the determination of variables has been the object of major discussions. Gallarza et al. (2002) revise quite thoroughly the different methodologies used in the studies on the image (understood, in the presented scheme, as displayed 
Table 2. Motivations and strategies of the displayed images.

\begin{tabular}{|c|c|c|c|}
\hline MOTIVATIONS & \multirow{12}{*}{$\leftrightarrow \rightarrow$} & \multicolumn{2}{|l|}{ STRATEGIES } \\
\hline Escape & & $\begin{array}{c}\text { Aesthetical } \\
\text { (enjoyable material element) }\end{array}$ & $\begin{array}{c}\text { Picturesque } \\
\text { (monumentality y lands- } \\
\text { cape architecture) }\end{array}$ \\
\hline Union/Family relation & & $\begin{array}{c}\text { Psychological } \\
\text { (evocation of emotions) }\end{array}$ & \multirow{3}{*}{$\begin{array}{c}\text { Emotional } \\
\text { (evocation of feelings) }\end{array}$} \\
\hline Relaxation & & $\begin{array}{c}\text { Unconscious } \\
\text { (subliminal adjectivation of the destination) }\end{array}$ & \\
\hline Social Interaction & & $\begin{array}{c}\text { Mythical } \\
\text { (fabled representations) }\end{array}$ & \\
\hline Novelty & & $\begin{array}{c}\text { Geographic/cultural } \\
\text { (natural-cultural singularity) }\end{array}$ & \multirow{2}{*}{$\begin{array}{c}\text { Unique } \\
\text { (exclusive attributes of } \\
\text { the area) }\end{array}$} \\
\hline Prestige & & $\begin{array}{c}\text { Strategic } \\
\text { (emblematic distinction) }\end{array}$ & \\
\hline Knowledge/Learning & & \multirow{5}{*}{$\begin{array}{c}\text { Infrastructural } \\
\text { (access, stay and alternatives) }\end{array}$} & \multirow{5}{*}{$\begin{array}{c}\text { Functional } \\
\text { (mobility, infrastructures, } \\
\text { access to activities) }\end{array}$} \\
\hline Rest & & & \\
\hline $\begin{array}{l}\text { Adventure/ } \\
\text { Entertainment }\end{array}$ & & & \\
\hline $\begin{array}{l}\text { Cultural } \\
\text { Experience }\end{array}$ & & & \\
\hline $\begin{array}{l}\text { Improvement or defence } \\
\text { of the ego }\end{array}$ & & & \\
\hline
\end{tabular}

Source: own elaboration based on Santana (2009) and San Martín (2005).

and perceived), classifying them according to their capacity to quantify the results, and in their case, the used technique for its capture and measurement. As for almost any uncertain process in the tourist system, the view of one discipline alone cannot do more than curtail the results and offer biased and partial conclusions. The image, as no other element, has to be analyzed with the epistemologies and methodological tools (and techniques) of multiple social and economic disciplines.

Most of the revised study cases are chosen by means of matrix-questionnaires (surveys) that are considered as structured techniques (battery of attributes fixed beforehand by the researcher) or non-structured ones (free descriptions) for the measurement of tourist destinations' image, even though from the end of nineties onwards, the combination of both becomes increasingly common. This combination has been shown to be very fruitful to the analysis of the destination's perceived image and the measurement both of the fulfillment of expectations and the motivations to make the trip, in so far as they make quantification and statistic prediction easier. Generally, the variables or set of attributes are determined through the review of other perfor- med studies, available in the academic literature, besides the ones highlighted form discussion groups with experts and in-depth interviews with key actors. In most cases, these are usually arranged in a survey, in which questions are formulated in a Likert's scale, to which open questions of short answer and a comments section are added. The tourists that will form the sample are categorized according to academic and research interests (almost never following any of the typologies in use), and the results will be processed-measured through different statistic procedures.

Traditionally, the anthropology has worked over more or less stable groups and territories, using the participant observation (field work) as main technique. By facing the study of a highly dynamic population (mainly tourists and foreign workers in the destination), the technique had to be adapted from survey-type analysis that identify and delimit as much as possible a typology of agents (basically displayed as actors of the tourist system) that is assessed. But the initial main component of the research comes hand in hand with the observation of such groups in their context. This way, an ideal research on the global image would take as observation 


\title{
Table 3. Considered descriptors for inclusion in the surveys to the different actors of the destination.
}

\begin{abstract}
General data
Socio-demographic characterization (sex, age, nationality, rural/urban provenance, education level, occupation, family's size, family incomes)

Characterization of the visit (Form of hiring/organization, expected length of stay, spent stay time, number of previous visits to the destination, general opinion of his/her previous travels (scale 1-7), number of travel companions, kinship with fellow travellers)
\end{abstract}

\begin{tabular}{|c|c|c|}
\hline $\begin{array}{l}\text { Cognitive variables } \\
\quad \text { (scale } 1-7)\end{array}$ & $\begin{array}{l}\text { Variety of information sources } \\
\text { (scale 0-9) }\end{array}$ & $\begin{array}{l}\text { Motivational variables } \\
\text { (scale 1-7) }\end{array}$ \\
\hline 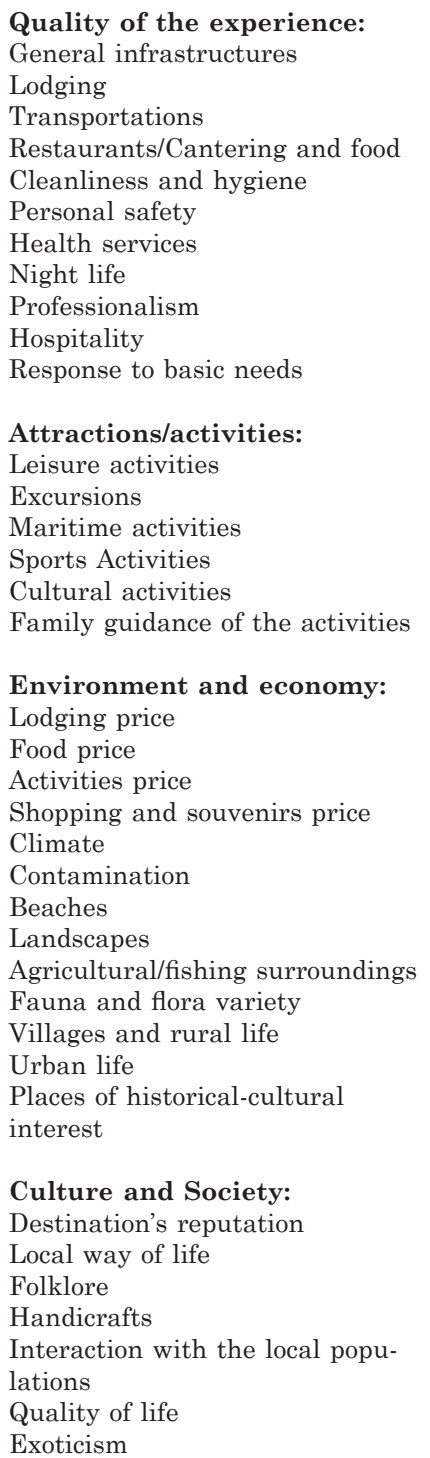 & $\begin{array}{l}\text { Valuation of institutional cam- } \\
\text { paign (scale 1-7) } \\
\text { Internet } \\
\text { Mailing } \\
\text { Leaflets } \\
\text { Understanding of the text } \\
\text { Exactitude of what is described } \\
\text { Quality of the photos/videos } \\
\text { General Presentation (Access) } \\
\text { Generating de expectations } \\
\text { Generating motives } \\
\text { Adaptation to one's needs } \\
\text { Ease of contact } \\
\text { Response capacity }\end{array}$ & $\begin{array}{l}\text { Relaxation and escape: } \\
\text { Relieving tensions and stress } \\
\text { Escaping the daily life's demands } \\
\text { Physical and mental relaxation } \\
\text { Escaping crowds } \\
\text { Breaking the routine } \\
\text { Excitation and adventure: } \\
\text { Doing exciting things } \\
\text { Searching for emotions } \\
\text { Beginning adventures } \\
\text { Having a good time } \\
\text { Knowledge: } \\
\text { Learning new things } \\
\text { Experiencing different cultures } \\
\text { and } \\
\text { ways of life } \\
\text { Enriching myself } \\
\text { Experiencing new/different places } \\
\text { Attend cultural events } \\
\text { Social and prestige: } \\
\text { Meeting people with similar } \\
\text { interests } \\
\text { Developing friendships } \\
\text { Being in places where my friends } \\
\text { have not been } \\
\text { Practicing new activities } \\
\text { Being able to tell my trip's } \\
\text { adventures }\end{array}$ \\
\hline
\end{tabular}

Source: own elaboration based on Echtner y Ritchie, 1991; Echtner y Ritchie, 1993; Baloglu and Brinberg, 1997; Baloglu and McCleary, 1999; Baloglu, 2001; Baloglu and Mangaloglu, 2001; Beerli and Martin, 2004; San Martín Gutiérrez et al., 2006) 
units both the main tourist emitting areas and the destination itself. Given the difficulty that it represents, in so far as dimension and characteristics of the research team, and economic and time costs are concerned, the observation units are usually limited to de visitation area, i. e., the destination becomes the sole study unit though the observation of the participant groups (subdivided according to spaces, actors, activities). Even though, with the expansion of the internet, these were added with the observation (and less often, the interaction) and the discursive analysis of more or less undetermined research subjects through different virtual networks (Facebook, Tripadvisor, ...).

The participant observation (unobtrusive interaction between the researcher and the informants) and the experimental observation (in which the observer acts causing situations), always guided by the research's design, may shed some light specially on the actors' behaviors and reactions, in addition to the global image. Within it, and as part of the used techniques for the obtaining of data, the conducted and non-conducted interviews, visual techniques (analysis of representations), life histories, discussion groups and the suitable for the group of variables expressed in table 3 .

Thus, the operational perspective offered by the mixed method research is proposed (Johnson \& Onwuegbuzie, 2004; Creswell \& Plano Clark, 2006; Johnson et al., 2007; Morgan, 2007; Pearce, 2012), combining data gathering techniques and quantitative and qualitative analysis in a complementary way (Creswell et al., 2007), and implied since the research's design phase.

Methodologically, in the concrete case of the self-image's study, this is begun determining the groups in presence, their range and representativeness. Based on structured interviews and questionnaires, a special attention is paid to the importance of its linguistic, territorial and socio-cultural attributes that will determine tangible referents (natural or created, from gastronomy to architecture) and intangible referents (stories, representations symbolization). The comparative analysis exercise of the different groups residing at the destination, plus their range and the groups' sociability, will indicate the common elements, perceptive dissonances and the adaptable traits to the tourist market's structure (convertible into products). It is, therefore, an exercise that may be carried out either in the initial steps of the development of the tourist destination, or when its identity is already established, showing then the possible distortions of this image regarding the displayed one. In this case, and after the aforementioned process, the same descriptors that determine the perceived image on the tourists' part will also be applied to the resident populations and interested parties, which will show the similarities or non-conformances with the self-, built and displayed image.

To the study and effectiveness validity of constructed image (specially the institutional campaigns) and of the shared image, data will be gathered from the descriptor indicated in table 3 (again expanding the actors range). In these questions, the data analysis is done in keeping with the seven codes that mainly define the images (psychological, aesthetic, unconscious, mythical, strategic, geographical/human and infrastructural) from an examination of content (text, photos, video, etc.). It will help to distinguish which stimuli are produced from the same codes, the adequacy to the self-image, the creation of expectations, the construction of a recollection and its dissemination, etc. A scarcely used tool is the analysis of the things that evoke the recollection, such as the pictorial representations taken in the destination, artifacts of any kind (sand, stones, pieces of wood, entrance ticket to shows, or any other tangible element that may be related to an activity, emotion or feeling) and the souvenirs or objects' purchases that are done.

\section{Conclusions}

The potentiality to act tourism is still constrained by the individual time and money surplus to access the tourist travel. But the accumulated tourist experience, the modifications in the motivational tendencies and the possibility to re-motivate the customer in the destination to the consumption of specific products and services, has opened the planet to tourism. All the territories and populations may devise something for the tourists' consumption, even though the ones that can count on the possibility to make themselves visible in the markets, to conveniently display their images for their potential clients, are less than others. These are the conditionings that have ultimately embedded with international destinations and tourist products in the Global Village. The post year 2000 tendency has prompted to look daily beyond the small borders, and, thus, by a threat of immediate loss, to focus on the localisms, to oppose the cultural hybridization. I. e., in strategies based on the conjugation of ideas, of essences and material relations, of significances and 
structures, melted in one voice or presentable in a supposed unity.

The tourist-image, culturally taken by many societies upon themselves, and progressively grasped as a process by others, is capable of generating non experienced recollections, spaces that are both desired and for the desire, promises of meeting other people, the equals to a smaller degree, the different above all, in principle hiding the differences, stressing them when the product so requires. Far from the good savage submitted to the Empire's dominions, the actors of the tourist system become an active part in the manipulation of the signs, producing, reproducing and consuming, according to the played role, as timeless simulations, the cultural forms that are effectively considered marketed. The clients of the tourist product, accomplices in the consumption of the authenticity, have been credited with the increase of their active role in the creation of significances. One should see who presents these significances, or at least the basic guidelines to infer them or 'innovatively' generate these new versions of significances in other areas. Originality is not exactly what prevails in the tourist destinations, whether they are cultural or of masses, or of any other kind, which leads us to believe that the hybridization's architects really exist.

In this text, a somewhat different way to contemplate the formation of the global image has been presented, a part of those hybridizations, in order to guide some ongoing researches and to contribute to the discussions on the theoretical and methodological tools, with the compromise that it is possible to establish a framework of understanding, criticism and discussion in the tourist system and the processes that take place in it.

\section{References}

Agarwal, S.

2006 "Coastal Resort Restructuring and the TALC Model". In R. W. Butler. The tourism area life cycle: conceptual theoretical Issues. Clevedon, Channel View Publications: 201$-218$.

Andreu, L.; Bigné, J.E. and Cooper, C.

2000 "Projected and perceived image of Spain as a tourist destination for british travelers". Journal of Travel \& Tourism Marketing, 9(4): 47-67.

Assael, H.

1984 Consumer behavior and marketing action. Boston: Kent Publishing.
Awang, K.W.; Wan Hassan, W.M. \& Mohd Zahari, M.S.

2009 "Tourism development: A geographical perspective". Asian Social Science, 5(5): 67-76.

Baloglu, S. and Brinberg, D.

1997 "Affective images of tourism destination". Journal of Travel Research, 35(4): 11-15.

Baloglu, S.

2001 "Image variations of Turkey by familiarity index: informational and experiential dimensions". Tourism Management, 22: 127-133.

Baloglu, S. and Mangaloglu, M.

2001 "Tourism destination images of Turkey, Egypt, Greece, and Italy as perceived by US-based tour operators and travel agents". Tourism Management, 22: 1-9.

Baloglu, S. and McCleary, K.W.

1999 "A model of destination image formation". Annals of Tourism Research, 26(4): 868-897.

Bardón Fernández, E.

1991 "El paisaje en la oferta turística recreativa”. Estudios Turísticos, 112: 27-54.

Baum, T.

1998 "Taking the exit route: extending the tourist area life cycle model". Current Issues in Tourism, 1(2): 167-175.

Beerli, A. and Martín, J.D.

2004 "Factors influencing destination image". Annals of Tourism Research, 31(3): 657-681.

Bigné, J.E.; Font, Xavier y Andreu, L.

2000 Marketing de destinos turísticos: análisis y estrategias de desarrollo. Madrid: ESIC Editorial. BULL

Bigné, J.E.; Sánchez, M.I. and Sánchez, J.

2001 "Tourism image, evaluation variables and after purchase behaviour: inter-relationship". Tourism Management, 22(6): 607-616.

Breakey, N.M.

2005 Tourism destination development. Beyond Butler. Thesis degree of Doctor of Philosophy University of Queensland. Avalaible: http:// espace.library.uq.edu.au/eserv/UQ:158161/ Breakey_Full_thesis.pdf

Butler, R.W.

1980 "The concept of a tourism area cycle of evolution: implications for management resources". Canadian Geographer, 24(1): 5-12.

Calantone, R.J., Di Benedetto, A., Hakam, A., and Bohanic, D.C.

1989 "Multiple multinational tourism positioning using correspondence analysis". Journal of Travel Research, 28(2): 25-32.

Castaño, J.M.; Crego, A. and Moreno, A.

2006 "Factores psicosociales y formación de imágenes en el turismo urbano: un estudio de caso sobre Madrid". PASOS. Revista de Turismo y Patrimonio Cultural, 4(3): 287-299. 
Chon, K-S.

1991 "Tourism destination image modification process: marketing implications", Tourism Management, 12(1): 68-72.

Coshall, J.T.

2000 "Measurement of tourist images: The repertory reed approach", Journal of Travel Research. 39(1): 85-89.

Creswell, J.W. and Plano Clark, V.L.

2006 Designing and conducting mixed methods research. Wiley Online Library.

Creswell, J.W.; Hanson, W.E.; Plano Clark, V.L. and Morales, A.

2007 "Qualitative Research Designs Selection and Implementation". The Counseling Psychologist, 35(2), 236-264.

Crompton, John L.

1979 "Motivations for pleasure vacation". Annals of Tourism Research, 6(4): 408-424.

Cruz Modino, R. de la

2004 "Patrimonio Natural y Reservas Marinas". PASOS. Revista de Turismo y Patrimonio Cultural, 2(2): 179-192.

Echtner, C.M. y Ritchie, B.W.

1991 "The meaning and measurement of destination image". The Journal of Tourism Studies, 2(2): 2-12.

Echtner, C.M. y Ritchie, B.W.

1993 "The measurement of destination image: an empirical assessment". Journal of Travel Research, 31(4): 3-13.

Fakeye, P.C. and Crompton, John L.

1991 "Image differences between prospective, first-time, and repeat visitors to the Lower Rio Grande Valley". Journal of Travel Research, 30(2): 10-16.

Fakeye, P.C. and Crompton, J.L.

1992 "Importance of socialization to repeat visitation". Annals of Tourism Research, 19(2): 364-367.

Franklin, A. and Crang, M.

2001 "The trouble with tourism and travel theory?" Tourist Studies, 1(1): 5-22.

Frías, D.M ${ }^{\mathrm{a}}$; Rodríguez, M.A. and Castañera, J.A.

2007 "Internet vs. travel agencies on pre-visit destination image formation: An information processing view". Tourism Management, 29(1): 163-179.

Gallarza, M.G.; Gil Saura, I. and Calderón García, $\mathrm{H}$.

2002 "Destination image. Towards a conceptual framework". Annals of Tourism Research, 29(1): 56-78.

Gartner, W.C.

1986. "Temporal influences on image changes". Annals of Tourism Research, 13(4): 635-644.
Gartner, W.C.

1993 "Image formation process". Journal of Travel and Tourism Marketing, 2(2/3): 191-215.

Getz, D.

1994 "Residents' attitudes towards tourism: A longitudinal study in Spey Valley, Scotland". Tourism Management, 15(4): 247-258.

González Bernáldez, F.

1981 Ecología y paisaje. Madrid: Blume.

González Bernáldez, F.

1985 Invitación a la ecología humana. La adaptación efectiva al entorno. Madrid: Tecnos.

Gunn, C.A.

1972 Vacationscape. Designing tourist regions. Washington, DC: Taylos and Francis/University of Texas.

Hunt, J.D.

1975 "Image as a factor in tourism development". Journal of Travel Research, 13(3): 1-7. Johnson, R.B. and Onwuegbuzie, A.J.

2004 "Mixed methods research: A research paradigm whose time has come". Educational researcher, 33(7), pp. 14-26.

Kozlowski, J.

1986 Threshold approach in urban, regional and environmental planning: theory and practice. St. Lucia: University of Quennsland Press.

Lawson, R.W.; Williams, J.; Young, T. and Cossens, J.

1998 'A comparison of residents' attitudes towards tourism in 10 New Zealand destinations". Tourism Management, 19(3): 247-256.

Lindberg, K. y Johnson, R.L.

1997 "Modeling resident attitudes toward tourism". Annals of Tourism Research, 24(2): 402-424.

Litvin, S.W. and MacLaurin, D.J.

2001 "Consumer attitude and behavior". Annals of Tourism Research, 28(3): 821-823.

Litvin, S.W. and Ng Sok Ling, S.

2001 "The destination attribute management model: an empirical application to Bintan, Indonesia”. Tourism Management, 22(5): 481-492 .

Ma, M. and Hassik, R.

2013 "An evolutionary perspective on tourism area development", Annals of Tourism Research, 41: 89-109.

Markwell, K.

2001 "An intimate rendezvous with nature? Mediating the tourist-nature experience at three tourist sites in Borneo". Tourist Studies, 1(1): 39-58.

Martín de la Rosa, B.

2003 "La imagen turística de las regiones insulares: las islas como paraísos". Cuadernos de Turismo, 11: 127-137. 
Mercille, J.

2005 "Media effects on image: The Case of Tibet". Annals of Tourism Research, 32(4): 1039-1055.

Morgan, D.L.

2007 "Paradigms Lost and Pragmatism Regained. Methodological Implications of Combining Qualitative and Quantitative Methods". Journal of Mixed Methods Research, 1: 48-76.

Murphy, P., Pritchard, M.P. and Smith, B.

2000 "The destination product and its impact on travel perception”. Tourism Management, 21: 43-52.

Nash, D.

1996 Anthropology of tourism. Oxford: Pergamon.

Parra López, E.; Melchior Navarro, M.and Ramos Domínguez, A.

2003 "Análisis e impacto de los touroperadores y las agencias de viaje en el transporte turístico: nuevas tendencias en Canarias". PASOS. Revista de Turismo y Patrimonio Cultural, 1(2): 217-229.

Pavlovich, K.

2003 "The evolution and transformation of a tourism destination network: the Waitomo Caves, New Zealand", Tourism Management, 24(2): 203-216.

Pearce, L.D.

2012 "Mixed Methods Inquiry in Sociology". American Behavioral Scientist, 56(6): 829$-848$.

Pinto da Silva Santos, R.

2010 "Padrones actitudinales de gestores en el turismo en Ilhéus, Brasil", Tesis Doctoral con mención europea. La Laguna, Tenerife: Universidad de La Laguna.

Rodríguez Darias, A.J.

2011 "Turismo en áreas protegidas. El caso de los parques rurales de Teno (Tenerife) y Betancuria (Fuerteventura)". Tesis Doctoral. La Laguna, Tenerife: Universidad de La Laguna.

Rodríguez, A.J.; Díaz, P.; Ruiz-Labourdette, D.; Pineda, F.D.; Schmitz, M.F. \& Santana, A.

2010 "Selection, design and dissemination of Fuerteventura's projected tourism image (Canary Isles)". In: S. Favro and C.A. Brebbia (eds.) Island Sustainability. Southampton: WITPRESS. (pp. 13-24)

Ronai, M.

1976 "Paysages". Hérodote, 1: 125-159.

Ryan, Ch. y Montgomery, D.

1994 "The attitudes of Bakewell residents to tourism and issues in community responsive tourism". Tourism Management, 15(5): 358-369 .
San Martín Gutiérrez, H.; Rodríguez del Bosque Rodríguez, I. and Vázquez Casilles, R.

2006 "Análisis de la imagen en turismo mediante técnicas estructuradas y no estructuradas: implicaciones competitivas para los destinos turísticos". Revista Asturiana de Economía, RAE, 35: 69-91.

Santana-Talavera, A.

2003 "Jugant a ser amfitrions: trobades i impactes en el sistema turístic". Revista d'etnologia de Catalunya, 22: 46-53.

Santana-Talavera, A.

2009 Antropología do turismo. Analogias, encontros e relaçoes. Sao Paulo, Aleph.

Smith, M. D. y Krannich, R. S.

1998 "Tourism dependence and resident attitudes". Annals of Tourism Research, 25(4): 783-802 .

Teye, V.; Sönmez, S.and Sirakaya, E.

2002 "Residents' attitudes toward tourism development". Annals of Tourism Research, 29(3): 668-688.

Um, S. and Crompton, J.L.

1990 "Attitude determinants in tourism destination choice". Annals of Tourism Research, 17(3): 432-448.

Valcuende del Rio, J.M. (Coord.)

2012 Amazonía. Viajeros, turistas y poblaciones indígenas. El Sauzal (Sp): PASOS Edita, 6. Available http://www.pasosonline.org/ Paginas/e-book_6.htm

Villa, Aurora D.

2001 "El turismo cultural o la mercantilización de la cultura”. In Arqueología, N.C.V.d.A.y. (Ed.), Congreso Virtual de Turismo 2001. http://www.naya.org.ar.

Westbrook, R.A.

1987 "Product/consumption-based afective responses and postpurchase processes". Journal of Marketing Research, 24(3): 258-270.

Recibido:

$21 / 05 / 2013$

Reenviado:

$21 / 06 / 2013$

Aceptado:

$01 / 07 / 2013$

Sometido a evaluación por pares anónimos 